\title{
The Last of the Romantics? Maoist Economic Development in Retrospect*
}

\section{Chris Bramall}

The notion that the development strategy pursued in China after 1949 had transformed the economy of the People's Republic was a staple of Western scholarship at the close of the Maoist era. Jack Gray's work of the early 1970s stood squarely within this tradition. ${ }^{1}$ For him, Maoism was superior to Stalinism as a transitional path to socialism because it avoided the "urban bias" inherent in the primitive socialist accumulation suggested by Preobrazhensky, practised by Stalin, and advocated for China by (inter alia) Bo Yibo (薄一波) and Liu Shaoqi. Instead of extracting resources from the rural sector, the late Maoist development strategy revolved around labour accumulation: the mobilization of rural labour to carry out rural industrialization, agricultural mechanization and the extension of irrigation networks. ${ }^{2}$

As Gray admits, this pro-peasant approach (modelled on the alternative transition strategy originally advocated by Bazarov, Shanin and Bukharin for the Soviet Union in the 1920s), was initially unsuccessful when tried in China during 1958. However, Gray argues, this was due to failures in implementation rather than conception: “... the tragic mess and the deep and bitter resentment among the rural population were not caused by the essential and original idea of the Great Leap, but by its perversion, and this perversion Mao damned in the most emphatic terms." 3 From this perspective, the Cultural Revolution was functionally necessary to revive the pro-peasant strategy: "This restoration of the original policies of 1958 was carried through only by a political revolution which broke the resistance of the vested interests which had been built up in the maintenance of a centralised system of economic planning and development and the urban-biassed services which this encouraged." 4 At the second attempt, the strategy worked: rural industry flourished, irrigated area expanded apace and living standards rose steadily in the 1960s and 1970s.

By the mid-1980s, however, this favourable verdict on Maoism had largely been abandoned. Two factors were at work. For one thing, the publication of systematic population and economic data on the late

\footnotetext{
* I am indebted to Tim Wright for his comments on an earlier draft, but the responsibility for the opinions expressed here are mine alone.

1. Jack Gray, "Politics in command," Political Quarterly, Vol. 45, No. 1 (1974), pp. 37-38.

2. The economics is usefully summarized in chapter three of the first edition of Paul R. Gregory and Robert C. Stuart, Soviet Economic Structure and Performance (New York: Harper and Row, 1974). A sign of the change in the climate of opinion is that these debates are accorded only three pages in the sixth (1998) edition of this popular text.

3. Gray, "Politics," pp 37-38.

4. Ibid. p. 41.
}

(C) The China Quarterly, 2006 doi: $10.1017 / \mathrm{S} 0305741006000312$ 
Maoist era by China's revived State Statistical Bureau painted a damning picture: the Leap had caused more than 20 million famine deaths; China's growth rate was slow when compared with other East Asian economies; over 200 million Chinese lived below the poverty line even at the close of the 1970s; and the urban-rural gap appeared to have widened during the 1960s and 1970s. Seen in this light, the notion that Maoism was pro-rural was no more than a neo-populist pipe dream. Secondly, the decollectivization of agriculture in the early 1980s was not only perceived as a "second emancipation" for the Chinese peasantry, but also appeared to have been a resounding success - suggesting that the road to development was via the reintroduction of market forces and the abandonment of Maoist-style labour accumulation. The collapse of the Soviet Union was the final blow to what was increasingly derided in the groves of academe as romantic Maoism. By the late 1990s, even the debate about "alternative roads to socialism" had become little more than a footnote.

It is evident that Jack Gray had no truck with this sort of revisionism. The central argument advanced in his 2006 article reiterates his earlier approach: the long-forgotten names of Bazarov and Shanin fairly leap off the page. For Gray, the late Maoist approach was no romantic dream, but rather a common-sense type of integrated village development strategy which used surplus labour to develop rural industry. And it was successful: the rural industries of the 1970s not only grew quickly, but provided the foundation for the explosive rural growth of the 1980s and beyond.

Now if one is to defend the Maoist development strategy, the defence must rest either on the claim that the performance of the Maoist economy was impressive, or that Maoism laid the foundations for the development of the 1980s and 1990s. The terrain staked out by Gray so trenchantly is the latter, and to this contention I will come in a moment. But first, what of the notion that the Maoist economic record was comparatively good?

\section{Maoist Economic Performance}

There is little mileage here in emphasizing the growth rates of GDP per person or per capita consumption. Retrospective official estimates, still more so the revisions to the data made by Maddison, demonstrate unequivocally that China's record, though historically impressive, was poor when compared with the growth rates achieved in many other countries, especially those of East Asia. ${ }^{5}$ Food consumption per head in the late 1970s in China may even have been lower than it had been in the 1930s. 
Nor is it a very convincing defence of Maoism to downplay the scale of the Great Famine (1958-62). Some continue to take this approach. For example, the distinguished Indian scholar Utsa Patnaik has claimed that the commonly-quoted figure of 30 million excess deaths is a "... retrospective, patently ideological construction." More precisely:

The figure of 30 million has passed into popular folklore. However, a study of how it has been arrived at shows that this estimate has no scholarly basis whatsoever. It is a travesty of the norms of academic integrity, that grossly exaggerated estimates of famine deaths derived in this arbitrary manner have been uncritically quoted and promoted and that they enjoy so much currency. ${ }^{6}$

But this sort of defence is doubly problematic. For one thing, it plays into the hands of those who would cast any defence of Maoism as morally equivalent to Holocaust denial. More importantly, the evidence leaves little room for equivocation, not least that contained in the County Records (xianzhi 縣志). Take Dayi (大邑), one of Sichuan's more than 200 counties. The data in the xianzhi reveal that there were 4,911 deaths in 1957. This figure rose to 31,872 in 1959, and peaked at 33,045 in 1960 before returning to 4,225 in $1962 .{ }^{7}$ If we assume that the 1957 death toll was normal, that implies total excess mortality of 67,204 during 1958-61. When applied to the whole of the province (Dayi's population was about 300,000 in the late 1950s), this produces an excess mortality total of over 14 million. Dayi may be unusual; the data I have collected for 30 different counties drawn from across Sichuan produce an average death rate which is about half the Dayi figure. But even if the Dayi mortality rate is halved to estimate the provincial total, it still gives over 7 million deaths in Sichuan alone. And although Sichuan suffered more than the average, the famine toll was high in several other provinces. There were nearly 2 million excess deaths in Anhui in 1960; in some of its counties, the death rate was about one in six. In Henan, the 1960 figure was around 1.3 million. Mortality rates were also high in Gansu and Guizhou. From all this, it is easy to construct national mortality totals which exceed 20 million. And, to repeat, these are actual deaths, not "hypothetical constructs." If we assume that births (and therefore infant deaths) were under-reported, or posit a counterfactual in which the death rate would have fallen below its 1957 level if the strategy of the mid-1950s had been continued, it is easy to generate a death total of 30 million or more. But no such assumptions are needed; the mortality data themselves point unequivocally towards a demographic disaster, and whether the number of deaths was 20 or 30 million has little qualitative significance for the way Maoism is evaluated.

6. Utsa Patnaik, "The republic of hunger" (10 April 2004) at http://networkideas. org/featart/ apr2004/Republic_Hunger.pdf (accessed 13.2.06), pp. 3-4. 1991).

7. Dayi xian zhi (Dayi County Records) (Chengdu: Sichuan renmin chubanshe, 
Of course there are many questions that remain to be answered about the famine. Perhaps the most important is whether official mortality rates should be taken at face value: the Party certainly has an incentive to contrast China's lyrical present with its unhappy past. But this is treacherous ground. An invented famine undermines the Party's historical record, and casts a dark shadow on the reputations of (inter alia) Deng Xiaoping and Bo Yibo, who were as culpable for the Leap as anyone else. If there is official distortion of data here, it is more likely to be an under-statement of the true mortality toll. These considerations, and the evidence on mortality, make it very hard to sustain the notion that Great Famine is a "patently ideological construction."

But there is no need to deny the famine in order to defend Maoism. It is much easier to stress China's impressive record on long-term capability improvement. The best comparison is with India. In the early 1950s, Chinese life expectancy at birth was about eight years higher than in India, but by the time of Mao's death, the gap had increased to about 13 years; only during the famine years of the early 1960s was the differential briefly reversed. Accordingly, even if we allow for famine deaths, the number of net lives saved in China as a result of improvements in health care and a more equal distribution of income far outweighs India's achievement over the same period. ${ }^{8}$ This sort of "net lives calculus" is undoubtedly distasteful, but it is one of the few sensible ways to think about China's relative development record.

An alternative defence of Maoist performance can be based around counter-factuals. If it is accepted that there is little to be gained by comparing developmental outcomes in China against outcomes in Taiwan, South Korea or India without some sort of proper discussion of the respective places of these countries in the post-war economic order, or of the legacies from the Republican and colonial eras, all sorts of possibilities open up. One might (as I have done in the past) defend Maoism by pointing to the constraints imposed upon economic development by China's political isolation in the 1960s and 1970s. Precisely because the People's Republic was denied the opportunity to trade, the potential of the economy was much reduced, and therefore actual outcomes should be judged against what was feasible rather than against some ideal. Still, this is slippery terrain. At a minimum, we have to ask whether China brought isolation upon itself; it is altogether too convenient to assume that there was no alternative.

A further counter-factual possibility would be to stress the constraints imposed on Maoist China by its dismal inheritance from the 1930s, and the contrast between this and the favourable colonial legacies enjoyed by Taiwan, India and Korea. But here too the

8. Jean Drèze and Amartya Sen, India: Development and Participation (Oxford: Oxford University Press, 2002), p. 127. 
arguments are not straightforward. Even accepting that the inheritance in other former colonies was favourable, recent work by Kirby, Rawski and Duara has tended to paint a more positive picture of the extent of state-building by the Kuomintang in the Nanjing decade, and from this one might infer that China was in some sense on the verge of economic take-off in 1937. I remain sceptical about this given the absence of any convincing evidence of accelerating agricultural growth, but these sorts of considerations need at least to be entertained if we go down the counterfactual road.

\section{Maoist Economic Legacies}

The other way to defend Maoist development is to focus less on economic and social accomplishments and more on its positive legacies. This is Gray's approach and to my mind it is the right one to take: the Deng-centred story of Chinese economic development after 1978 - in which policy change of one form or another is virtually all that mattered - has too much of the fable about it.

Still, we need to be careful. It is for example hardly profound to assert that developments in the Chinese economy were driven as much by continuity as by change. Of course, there is a great deal to be said for sweeping aside the "great divides" of 1949 and 1978 in thinking about Chinese economic history, but there can be no simple inference that Maoist legacies were growth-promoting. Take, for example, the educational legacies. Much evidence suggests that literacy rates increased significantly in China's poorest provinces under Mao. If we further assume that a literacy rate of around 40 per cent is necessary for modern economic growth - the famous BowmanAnderson threshold - it may well be that Maoist educational expansion was desirable on instrumental as well as intrinsic grounds in these provinces. In eastern China, however, the educational case for Maoism is less easily made. There is, for example, a good deal of evidence suggesting that literacy rates were rising rapidly even during the 1930s in provinces such as Jiangsu, and therefore that Maoist policies were unnecessary. Moreover, even if we credit Maoism for continued educational expansion in eastern China after 1949, it is not clear that increasing literacy rates above the 40 per cent threshold had much by way of a pay-off in terms of subsequent growth. ${ }^{9}$

For his part, Gray emphasizes the industrial legacies of Maoism in the countryside. His argument is that Maoism created a rural industrial sector which was expanding rapidly during the 1970s, and which would have continued to grow even in the absence of any post1978 policy changes. He is not alone. Perkins and Putterman have

9. Lant Pritchett, "Where has all the education gone?" World Bank Economic Observer, Vol. 15, No. 3 (2001). The provinces of Zhejiang and Jiangsu grew very fast after 1978 despite an educational inheritance that was little better than the Chinese average. 
made a similar point, and even those who emphasize the contribution made by policy change (such as Whiting) have noted the institutional legacies of Maoism. ${ }^{10}$ It is admittedly true that few have pushed the argument quite as far as Jack Gray. Yet much of the evidence supports his interpretation. Late Maoism was certainly characterized by industrial bias because the internal terms of trade were biased against agriculture (in the sense that the relative price vector diverged from its notional equilibrium value). However, the very scale of rural industrialization suggests that the case for urban bias is much less powerful. ${ }^{11}$ My reading of the evidence is that both the Third Front programme (at least in its essentials) and the promotion of countyowned industries should be seen as policies which promoted rural industrialization, and their success can be measured by the growth in industrial output during the 1970s. Of course much of the late Maoist rural industrial sector was inefficient (as Gray himself notes), but it is not hard to argue that rural industrialization led to the acquisition of skills ("learning by doing"), and hence to creation of a skilled workforce. Other countries which have attempted to develop rural industry in recent years (Vietnam and India both come to mind) have arguably failed because they lacked this inheritance. Whether rural industrial take-off - in the sense of a self-sustaining process of growth - would have occurred without post-1978 policy changes is more controversial; in my judgement, that contention probably takes us a bridge too far. Nevertheless, there is a compelling case for concluding that the industrial inheritance was a necessary condition for the rural industrialization of the 1980s.

A powerful argument for continuity can also be made vis-à-vis agriculture. Although it is widely believed that decollectivization was the catalyst for accelerating agricultural growth, the evidence points to a turning point in the early 1970s when three Maoist policies came together: the expansion of irrigated area via the mass mobilization of rural labour (a process, as Gray rightly notes, begun in the late 1950s), the availability of new high-yielding seed varieties developed in Chinese research stations during the 1960s, and increased production of chemical fertilizer in factories based mainly in the countryside. ${ }^{12}$ This "green revolution" package proved remarkably effective; yields rose sharply in the 1970 s, and it is entirely reasonable to see the agricultural expansion of the early transition era as driven by

10. Dwight H. Perkins, "Have China's economic reforms stalled?" in Wang Gungwu and John Wong (eds.), China's Political Economy (Singapore: Singapore University Press, 1998); Louis Putterman, "On the past and future of China's township and village-owned enterprises," World Development, Vol. 25, No. 10 (1997); Susan H. Whiting, Power and Wealth in Rural China (Cambridge: Cambridge University Press, 2001).

11. The best study of intersectoral resource flows is that of Sheng Yuming, Intersectoral Resource Flows and China's Economic Development (London: Macmillan, 1993).

12. Bruce Stone, "Developments in agricultural technology," The China Quarterly, No. 118 (1988). 
diffusion of this package. To put it another way, agricultural output would have surged in China without decollectivization, and perhaps even without the 1979 increase in procurement prices.

If we are to use the language of climacterics, China's true economic watershed was probably 1972. By that time, the agricultural revolution was in full swing, and the rapprochement with the United States undoubtedly facilitated growth by allowing an expansion in Chinese foreign trade (enabling, for example, the importation of chemical fertilizer plants). Thus the contribution of "the West" to China's recent economic success needs to be recognized at the same time as we give due credit to the long-term legacies of Maoism; to focus exclusively on the role of internal factors in driving growth would, I think, be as wrong as explaining growth in terms of the open door policies of the 1980s and 1990s. It is not perhaps terribly romantic to see Nixon and Mao as the twin saviours of China - I rather doubt that Jack Gray would have thought so - but there is a strong case to be made along these very lines. 